\title{
SUSTAINABLE DEVELOPMENT OF URBAN CONSERVED HERITAGE: AN ANALYTICAL STUDY OF KURSUNLU MOSQUE IN ULUS, ANKARA
}

\author{
KABILA FARIS HMOOD ${ }^{1} \&$ GÜLŞEN DISSLI ${ }^{2}$ \\ ${ }^{1}$ Al-Zaytoonah University of Jordan, Department of Architecture, Amman, Jordan. \\ ${ }^{2}$ Necmettin Erbakan University, Faculty of Engineering and Architecture, Department of Architecture, \\ Konya Turkey.
}

\begin{abstract}
Sustainable design movement in Turkey and across the world mostly focuses on new buildings, with little attention on existing built heritage. Nonetheless, historical building heritage constitutes a majority of the built environment in Turkey. According to the statistics of Turkish Ministry of Culture and Tourism, there were 106.359 registered immovable cultural heritage in all around Turkey at the end of the year 2017. It is thus important to investigate sustainable development potentials and make suggestions for conserved built heritage. The aim of this research stems from the importance of finding a clear visualization for urban design for cities in the present and future by means of sustainable development, which satisfies the needs of the present and protects the rights of the future. Hence, this manuscript first examines the sustainability potentials of a case study in the 16th century Kursunlu Mosque with its neighbourhood, located in the historic Ulus district in Ankara, Turkey. This research investigates the importance of studying the term 'urban conservation' within the context of historic Ulus area. Although the mosque is nearly walking distance to historic touristic destinations of Ankara such as the Castle, Ahi Elvan and Ahi Serafettin Mosques, Cengel Khan (Museum), Cukur Khan, Safran Khan and Hamamonu area, it does not attract much of the visitors, because of its lack of integrity with the nearby built environment and its restoration necessity. Research methods include literature and archival survey, in-situ observations, and interview with the local community. The analysis reveals urban conservation potentials of the area and sustainable development suggestions for the mosque with its neighbourhood. The major conclusion of the research is that sustainable development suggestions as well as conservation measures of the case study mosque and urban conservation analysis may provide the user and visitor increase and contribute to the revitalization of the building and the neighbourhood area in the long term.

Keywords: Existing built heritage, Historical cities, Kursunlu Mosque, Revitalization, Sustainability, Ulus, Urban and architectural heritage, Urban conservation, Urban fabric.
\end{abstract}

\section{INTRODUCTION}

Historic cities do not just consist of old buildings and physical environments, but also the memories and traditions of the inhabitants created by the societies over the centuries [1]. Hence, it is of vital importance to treat the sustainability and urban conservation with a holistic approach, where one cannot be separated from the other. Considering this reality, this paper aims to set up the relationship between sustainability and urban conservation based upon the authors' work in Ankara, restricted to within the historic Ulus district. The 16th century Kursunlu Mosque and its urban context has been selected as the sub-region in this case study area in order to analyse the sustainability potentials in historic urban cores. In this research a descriptive analysis method has been used, which relies on the following research hypothesis: the ideal and efficient way of our urban and architectural heritage conservation could be achieved by sustainable urban conservation as the first step in order to realize sustainable architectural heritage. The World Heritage Convention, Article 1, similarly supports that hypothesis by defining the cultural heritage as the combination of 'monuments, groups of buildings, and sites' [2]. For this reason, historic sites and urban districts are as important 
as architectural heritage buildings, such that, a broad set of different typologies has emerged consisting of historic urban centres, archaeological and cultural sites, landscapes, and heritage routes [3]. As a result, various experts with different skills are required in order to manage the increasing range of historic places and landscapes.

There is broad literature on sustainability and conservation. Among them to Rodwell, holistic approach is required in heritage conservation in connection with the sustainability [1]. Thus, it becomes possible 'to determine the least interventionist approach to the society, environment, and economy of an historic town by allowing the use of buildings, the plot sizes, street patterns, and open spaces, together with the traditional patterns of use, movement, and the human culture' [1]. He further asserts that both architectural and urban conservation have a close relationship and have the potential to contribute to the sustainability [4]. Doak and Lynch outlined the positive elements of this relationship as 'traffic, environmental capacity, quality of life, mixed use, energy efficiency, tourism, and regeneration', and determined the conflicts as 'variability in conservation area quality, traffic displacement, building maintenance and improvement costs, inequity, lack of integration, and tourism' [5]. There are also cases studies. As an instance, Elborombaly, in his research analysed two Arab cities and proposed a methodology for their sustainable urban conservation, and similarly Malia studied the issue of sustainability and urban conservation with the case of Maltese island [6]-[7].

There is also considerable literature on the historic Ulus district, on its heritage conservation, architecture, archaeology, and historic development. Among them, Güner studied Sakarya Quarter in Ulus, to determine general characteristic and values of the area in order to find the role of social sustainability in heritage conservation [8]. Similarly, Ünver concentrated her research focus on the Keklik Street in Ulus evaluating the area in terms of its sustainability principle of cultural heritage management [9]. Other studies, examined the historic architecture of the district including historic buildings belonging to different periods [10]-[12].

Yet, different from all the existing literature, this research focusses on the analysis of urban conservation potentials of Ulus district, and sustainable development suggestions for the 16th century Kursunlu Mosque and its neighbourhood. This study is significant as it provides data on their contributions to the revitalization of the area.

\section{URBAN HERITAGE CONSERVATION: THE CASE OF ULUS DISTRICT, ANKARA}

\subsection{Urban conservation}

Urban conservation, which is attached to the urban fabric as a whole, can be defined as 'the process which cares about the quality of the urban environment, through putting a program which helps protect cities and urban areas, along with excluding these areas from environmental and visual pollution' [13]. The increased attention given to the historic city centres is not due to socio-economic reasons only, but also due to some facts related to the context and environment, such as the cities' historical centres are a fabric of historic buildings and roads from different periods, which create a diverse cultural and architectural structure. In addition, modern pressures affect the preserved buildings and their cultural urban context [14].

Before World War II, the attention of European countries was limited to important historical buildings only, but in post-war period, European countries managed to take quick and 
positive steps towards protecting their urban heritage to conserve urban fabric and style of the old city [13]. At present, similarly, heritage conservers are all responsible for achieving an urban pattern connecting the new with the old successfully, by providing a clear link between conservation of the urban and architectural heritage, and contemporary building.

Historic Arab cities, which combine the old and modern in their central urban fabric, have varied in their urban policies. In Sidi Bou Said city in Tunisia, the whole town was preserved including, the road network, and particularly the urban structure with the addition of modern elements in the form of urban infill, aiming to achieve a tourist attraction serving both the needs of the tourists and residents (Fig. 1). A similar situation is also demonstrated in the city of Sousse, in which the old was preserved and the new was constructed with the same materials, height, and architectural style of the old. Hence, an identical approach is applied in designing new infills. There are many other cities which are aware of the importance of conserving its urban and architectural heritage, such as Istanbul, Madrid, Cairo, Tunis, Fez, Paris, Vienna, Moscow, Baku, London, Leipzig, Boston, and Danzig (Figs. 2 and 3). These cities are preserved partially, or substantially, the historic public buildings in the main parts or by-streets of the city, in an attempt to create the needed harmony between the modern and old, in the whole urban fabric.

Taking into account that preserving the urban and architectural heritage helps preserve the identity of societies, UNESCO provides financial and scientific assistance to many countries in order to save their world heritage. Most of the heritage conservers agree on the development of preservation policy of urban and architectural heritage based on two aspects; the first one aims to develop and preserve the planning units inherited architecturally, while the second one is interested in processing the recent buildings and urban fabric in a manner that does not harm the heritage inventories [14]. This second aspect represents the concept of 'dual cities'; namely, while the old parts preserve their architectural style, the modern areas are developed in harmony within the identity of historic city. As a result, urban conservation applied urban renewal policies, which maintains the urban fabric and structure of the inherited city and modern demands of human beings as well, aiming to find a way towards sustainable development of heritage [15]. Such a sustainable development establishes and reinforces identity, supports culture, and helps renew heritage tourism, which increases
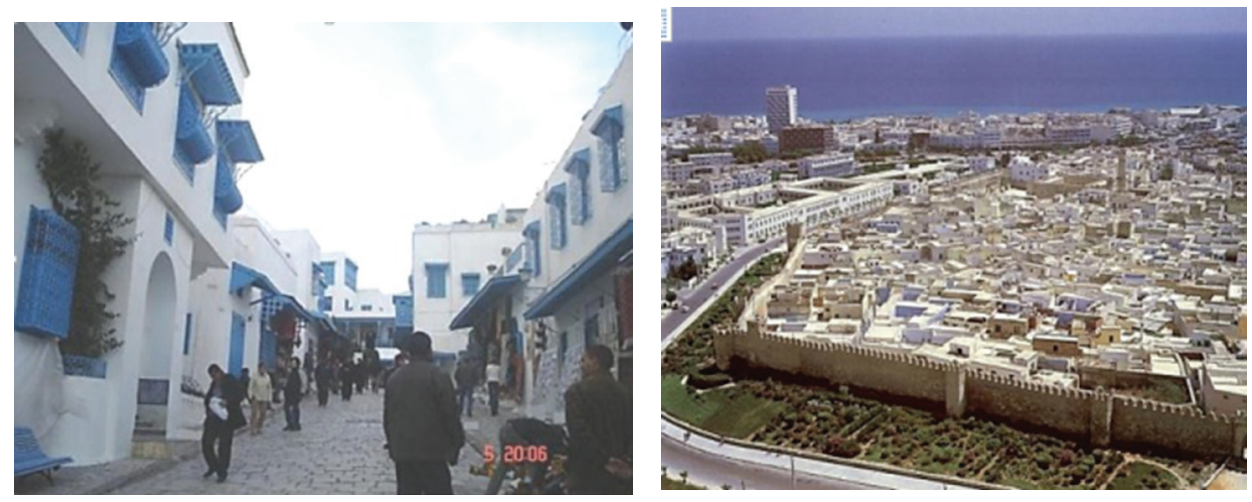

Figure 1: Tunisia preserves its architectural and urban structure and the network of roads in many traditional city such as in Sidi Bou Said (left) and Sousse (right) (photos: authors' archives, 2005, and [17]. 

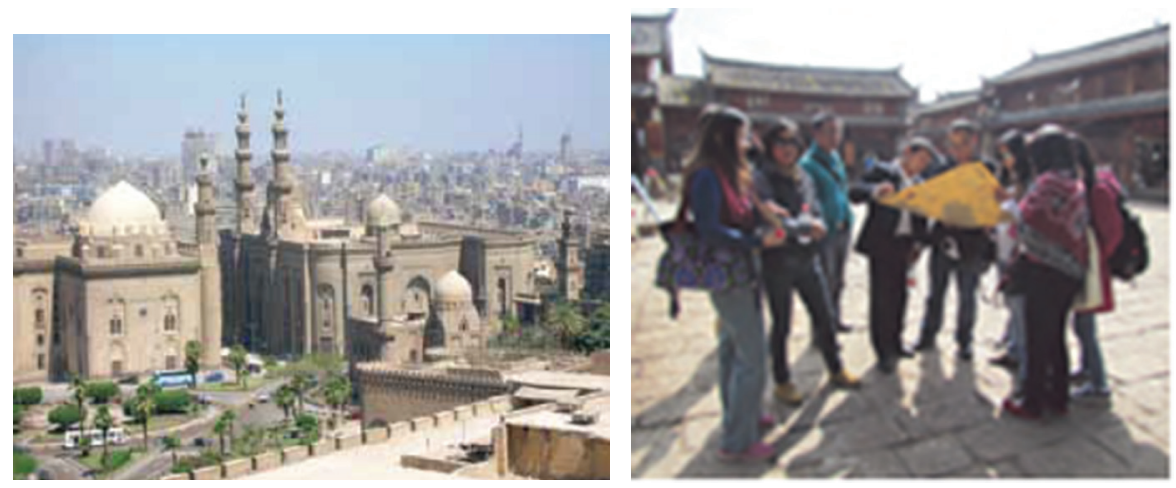

Figure 2: Historic Cairo/ Egypt (left) and Old Town of Lijiang (China) (right) [3].


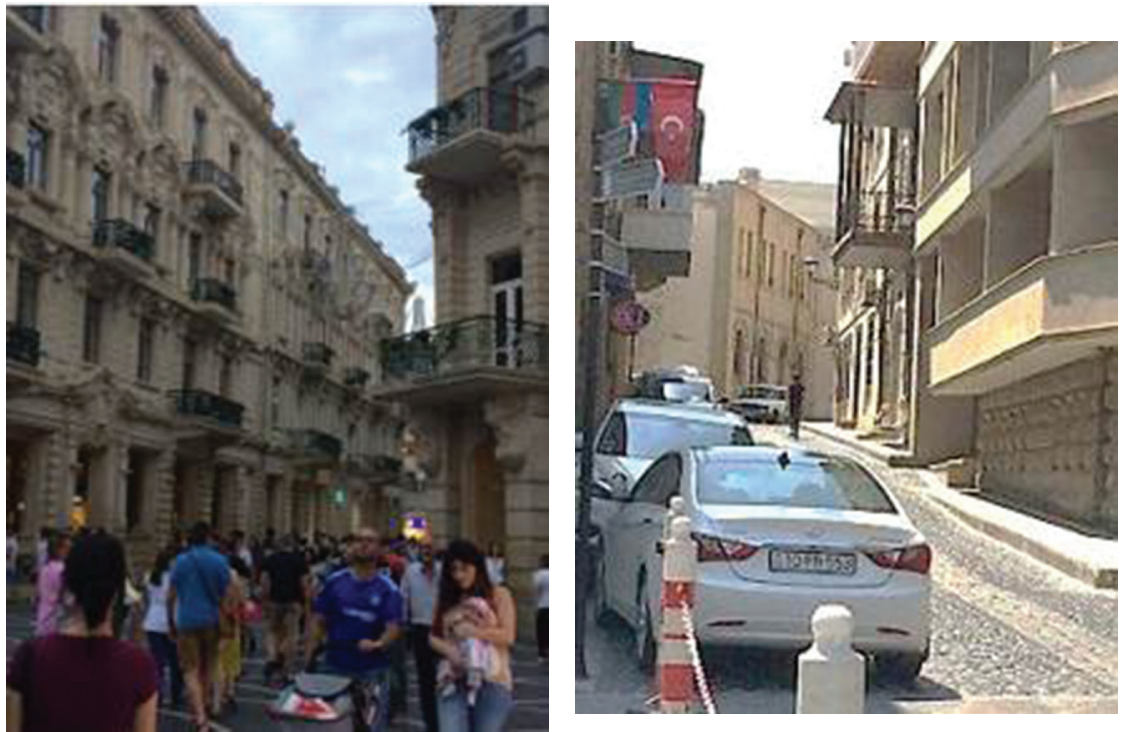

Figure 3: Examples of cities that are aware of the importance of conserving its urban heritage and the architectural one, as well. Top left and centre, Alicante, Spain; top right, Granada, Spain; and bottom left, centre, and right, Baku, Azerbaijan, old city centre (photos: authors' archives, 2017-2018).

awareness of the importance of sustainable heritage conservation, since heritage tourism depends on the quality of natural and cultural environment. Environmental preservation has also given rise to what is known as green tourism. Hence, maintaining the authenticity of heritage sites and collections is important and essential for preserving their cultural significance [16]. The living heritage sites are also considered important because they tell us about the past, and give testimony of the continuity of old traditions in present-day culture, and at the same time provide implicit evidence for their sustainability [3]. Because of the major phenomena such as globalization, demographic growth, and development pressure in recent years, greater importance is given to sustainable use and development of heritage. This is why the cultural heritage sector has started to focus more on the relationship between conservation and sustainable development.

\subsection{Contributions of Ulus district to urban conservation in Ankara}

Historic Ulus district was once the heart of old Ankara, the capital of Turkey. The name means 'nation' in the Turkish language. It is now predominantly a commercial and touristic centre with many historical buildings and structures such as one of the city's oldest hotels, the Ankara Palas, in which Atatürk had also stayed for a while (Fig. 4). In addition, Ankara Citadel, Roman Bath, Augustus Temple, historic khans such as Çengel Khan, Çukur Khan, and Safran Khan, all used in different functions today, historic mosques including Ahi Serafettin, Ahi Elvan, Hacı Bayram-1 Veli Mosque, tombs, baths, and museums are all located in Ulus district (Fig. 5). Ulus district can be considered partially as an example of 'dual cities' achieving the concept of 'urban conservation,' in which the older parts preserve their traditional architectural style, while at the same time modern areas are developed. In Ulus, in some limited parts, 


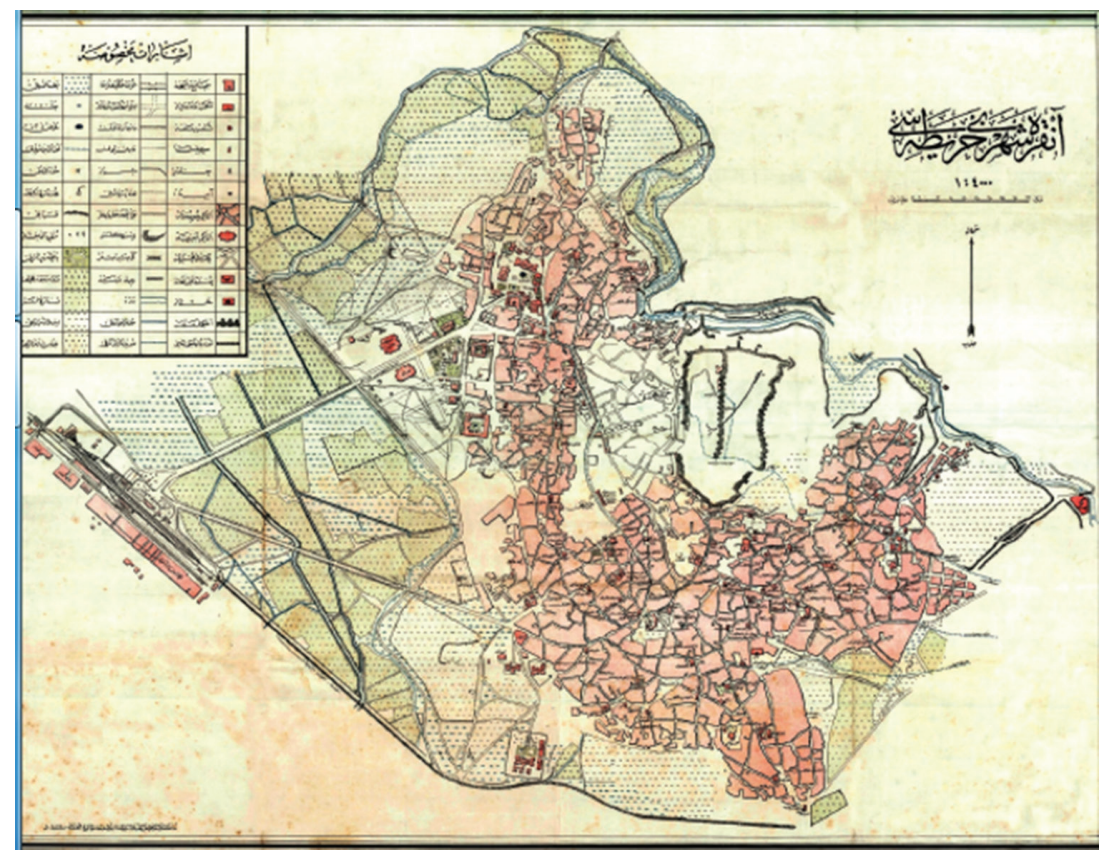

Figure 4: 1924 Map of Ankara City [20].
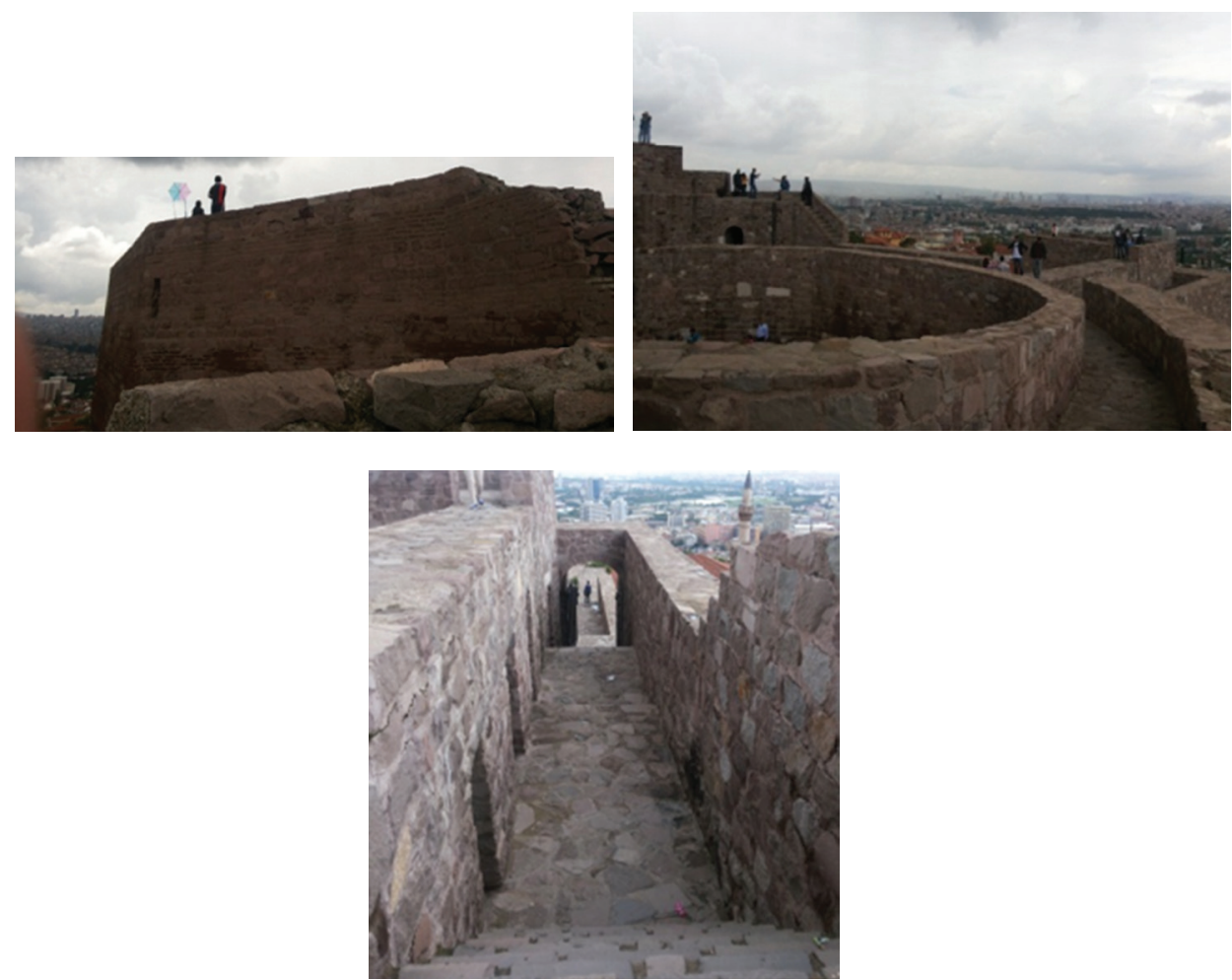

Figure 5: Ulus, Ankara Citadel centre (photos: authors' archives, 2014). 
it is still possible to find a strong link between the old urban fabric and the modern development in a way in terms of the urban structure and road network as in Hac1 Bayram-1 Veli Mosque, Ankara Castle, and Hamamonu where vehicle entrance times were limited and pedestrian zones are increased (Fig. 6). Ulus also preserves its heritage to some extent in a sustainable way by applying rehabilation and refunctioning of many old buildings and creating open spaces, which meets the modern needs of todays users [18] (Table 1). In addition, similar to typical Ottoman cities, Ulus is also a layered settlement of Ankara, including mosaic and syntesis of different traces/stratas from many civilizations such as Phrygians (8th century BC), Galatians (3rd century BC), Romans (1st century BC), Byzantines (4th century), Seljuks (12th century), and Ottomans (14th century) [19]. Traditional houses with projections and high-walled courtyards, organic labyrinth-shaped narrow streets, inclined terrain, traditional street pattern, dead-end streets, and assembly areas around the historic mosques and trade centers, which are typical to Ottoman cities, are also still observable in some limited parts of todays Ulus region (Fig. 7). Though most are lost today, fountains in traditional districts are
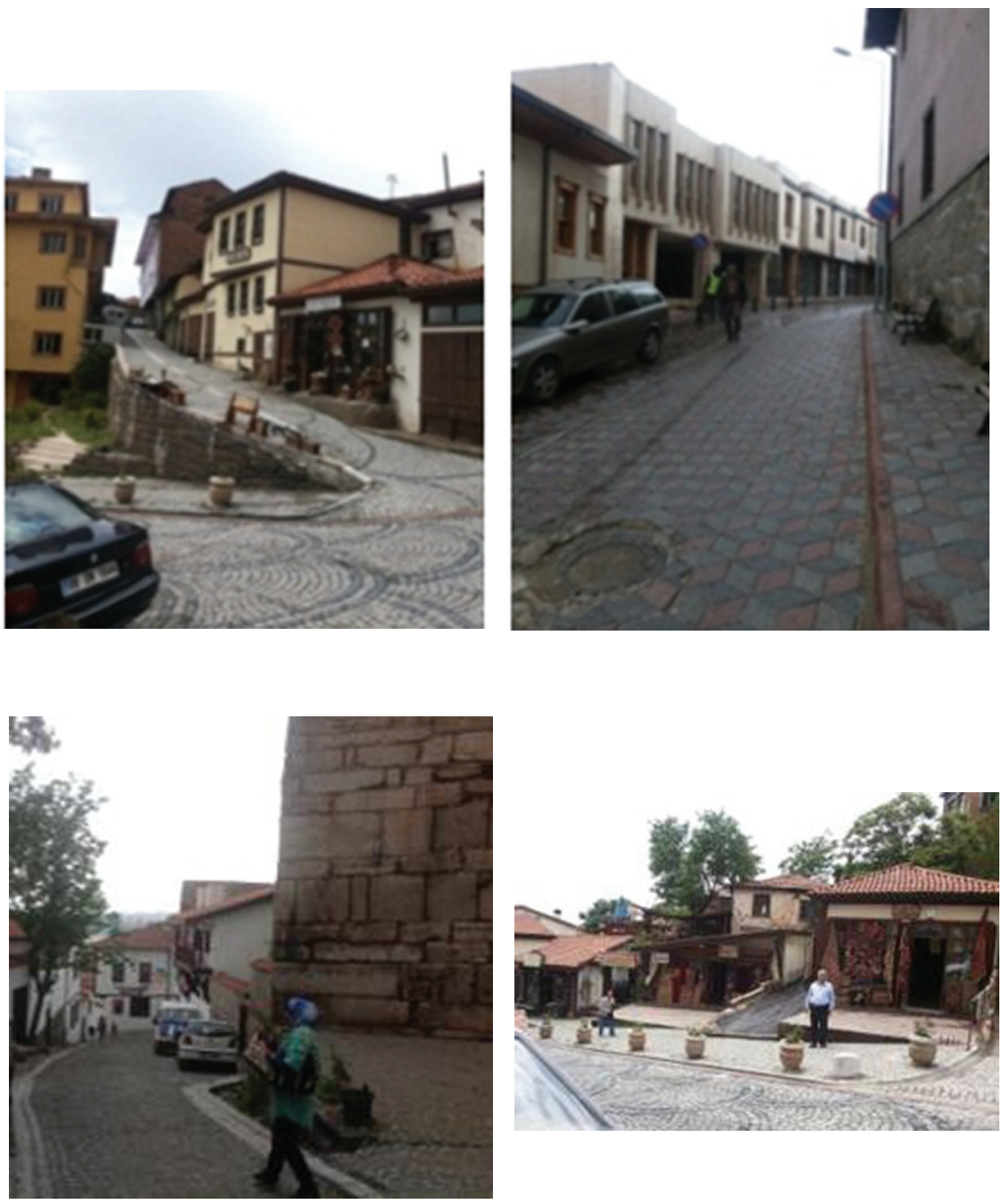

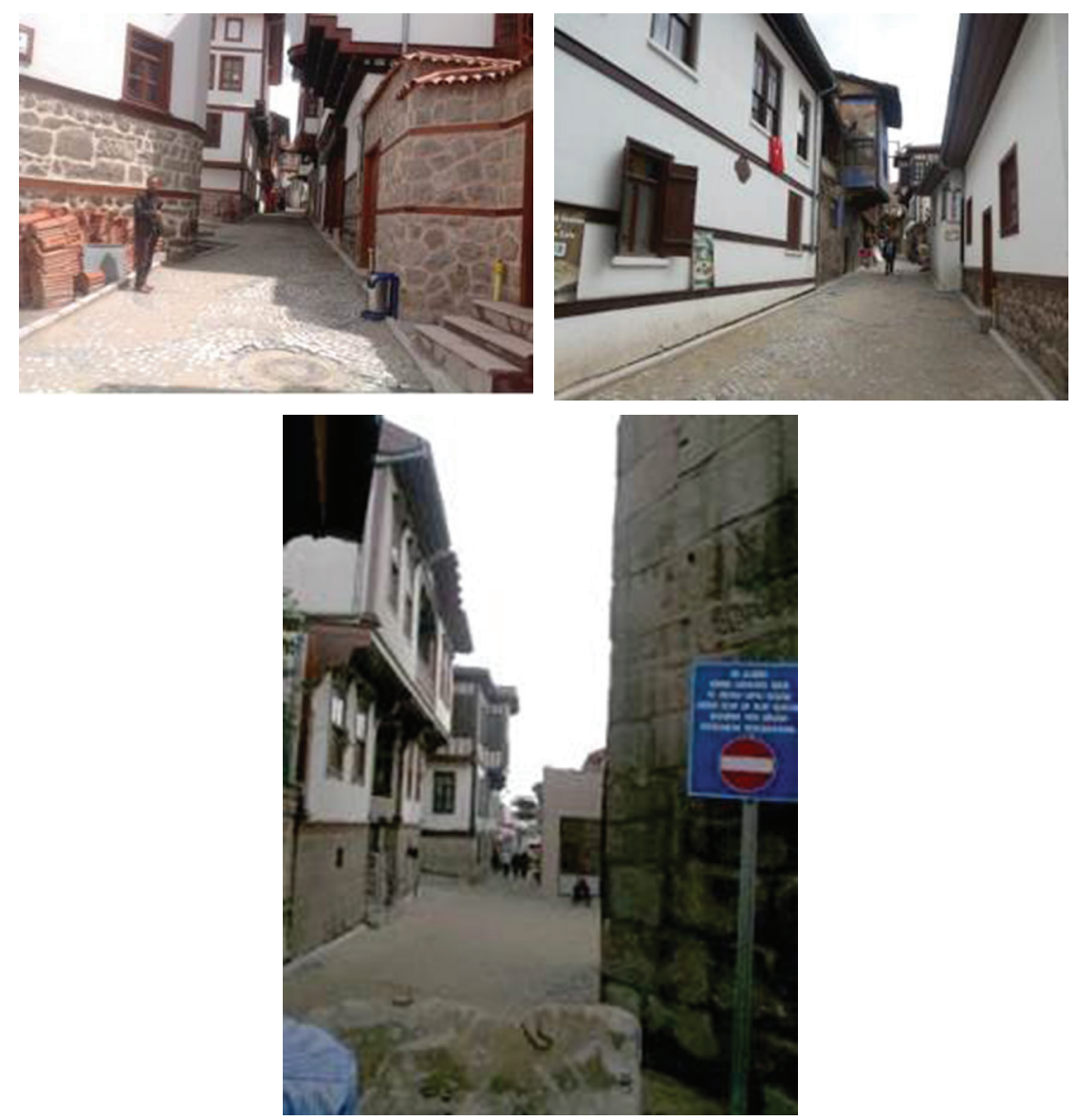

Figure 6: Views from Ulus, Ankara, showing the urban conservation of its structure and roads in a way which adapts with the old (photos: authors' archives, 2014).

similarly important parts of organic street pattern in Ulus. However, it should be noted that the area is losing its character defining features each day due to inappropriate concrete new additions and infills to the historic built environment. Other possible contributions of Ulus District to urban conservation of the City of Ankara are explained below:

- Public space plans, common space designs and community involment in urban cores (i.e. common public space development around Cengel Khan, Cukur Khan, Safran Khan region, Hacı Bayram-1 Veli Mosque, and Augustus Temple, Hamamonu area)

- Economic development plans in historic urban centers (i.e. Ankara Citadel and its nearby surrounding area, Hamamonu area, Hacı Bayram-1 Veli Mosque district)

- Traffic regulations; increased public tranport alternatives such as subways, buses and minibuses, pedestrian access in sensitive areas, controlled vehicle traffic, regular parking lots (i.e. area around Ankara Citadel and Hac1 Bayram-1 Veli Mosque)

- Contribution to economic quality of life in conservation areas in the form of touristic attraction, thus serving for job opportunities for the local community (i.e. Hamamonu District, Ankara Citadel and its nearby area), thus encouraging urban revitalization, 
Table 1: Ulus preserve its heritage by applying rehabilation to many old buildings and open spaces (photos: authors' archives, 2014, 2018).

\begin{tabular}{|c|c|c|c|c|}
\hline & \\
\hline & & \\
\hline
\end{tabular}
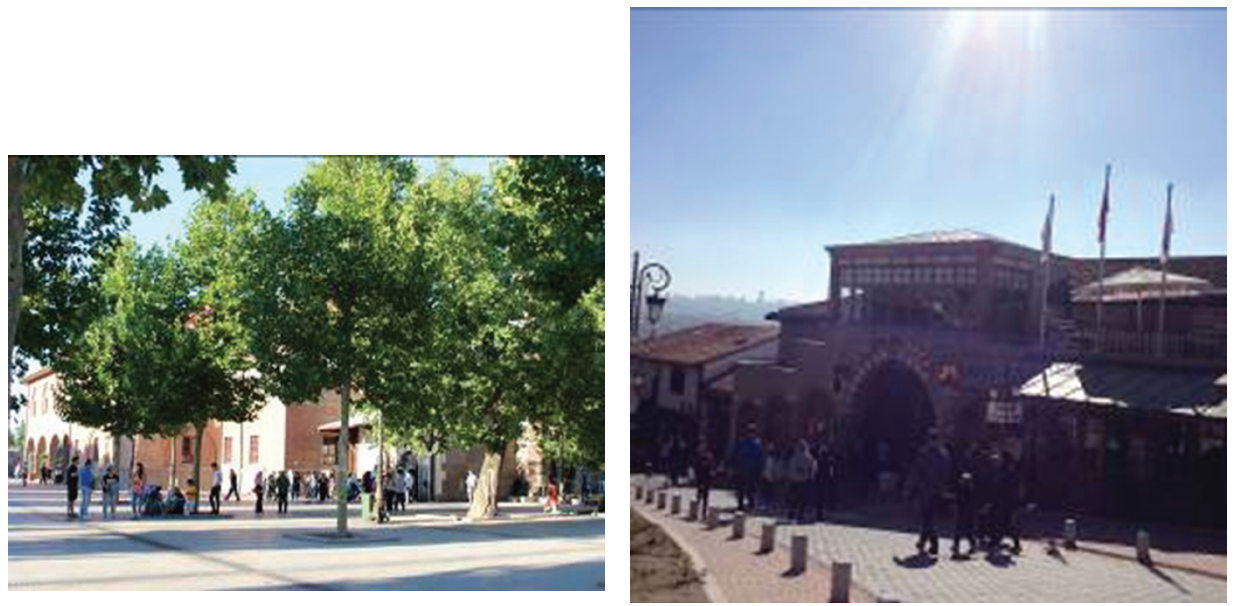

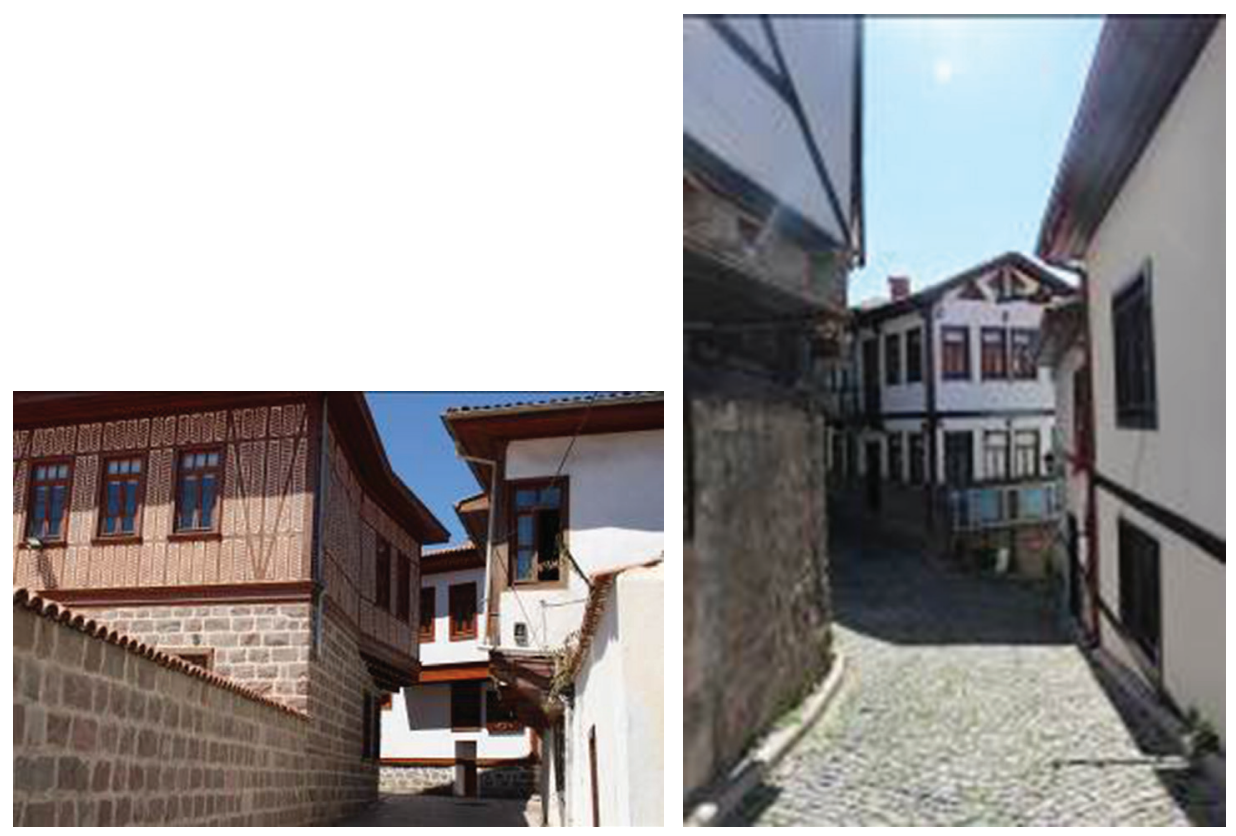

Figure 7: Views from common public spaces around Hacı Bayram-1 Veli Mosque, and khans region, and views of organic narrow street patterns in Ulus (photos: authors' archives, 2018).

- Preserved historic, social, and cultural value of the conservation areas (i.e. Cengel Khan, Cukur Khan, Safran Khan region),

- Contribution to energy efficiency, promotion of usage in natural resources by means of adaptive reuse and architectural conservation activities in the area (i.e. Cengel Khan, Cukur Khan, Safran Khan region),

\section{INVESTIGATING THE SUSTAINABILITY POTENTIALS OF KURSUNLU MOSQUE AND ITS NEIGHBOURHOOD AS AN EMPIRICAL CASE IN ULUS DISTRICT}

\subsection{Placing the Kursunlu Mosque: shopping + worship + touristic loop}

Built in the 16th century, it is designed in the Classical Ottoman style (central plan mosque style), with one large main central dome above the main prayer area [11]. The structure has two story main body walls with a square plan covered with a dome. The dome has an octagonal drum. There is a circular minaret located on the northeast façade of the mosque rising above a pentagonal base with a single balcony, and a pointed cone. After the earthquake in 1921 it was renewed [11]. The late comers' portico of the mosque was closed first with a oneway sloped roof. Then it was built again in 1972 enlarged with a two-story concrete column and beam system [11-12]. This new addition is used for women's prayer space and children's education and its basement floor is used for toilets, ablution hall, and for water depot. Neither the material selection, nor the form, geometry, and style of this new addition is compatible 
with the old mosque, such that it totally prevents the visibility of the original mosque on the north façade [21]. The mosque itself still preserves its original function as a prayer place. The exterior finish of the mosque is rubble stone with alternating brick rows façade detailed with rectangular windows at the first level with pointed arched brick pediments, pointed arched windows at the drum level, and a dome topped with a copper finial (Fig. 8). At the interior the main prayer area is covered with a dome with squinches on the corners (Figs. 9 and 10). There is a plaster mihrab with muqarnas niche, and with Qur'anic inscriptions, geometric bordures, rosettes, and ornaments on the south façade of the main prayer area. There is not any historic value of the wooden minbar, and it is dated to recent history [11]. Kursunlu Mosque was repaired in 1914 by the local community, and then in 1990 by Directorate General of Foundations, in 1982 its minaret was repaired and repointings of main body walls were renewed [12], [22]. On the 31 March 1964 it was registered as a historic place by the Conservation Board of Historic Properties [22].
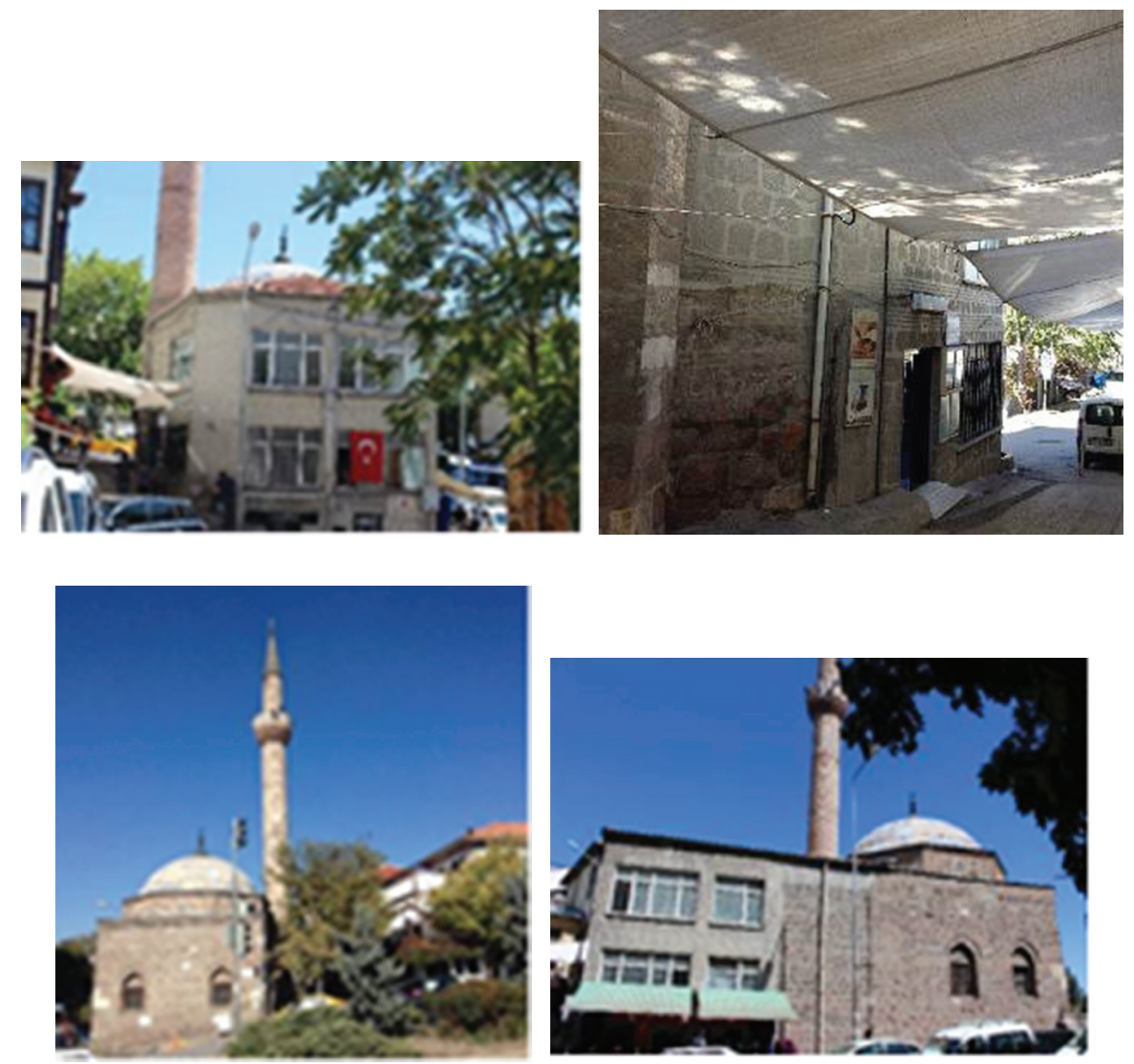

Figure 8: North, east, south, and west facades of the mosque (from left to right)

Source: Archives of the authors, 2016, 2018. 

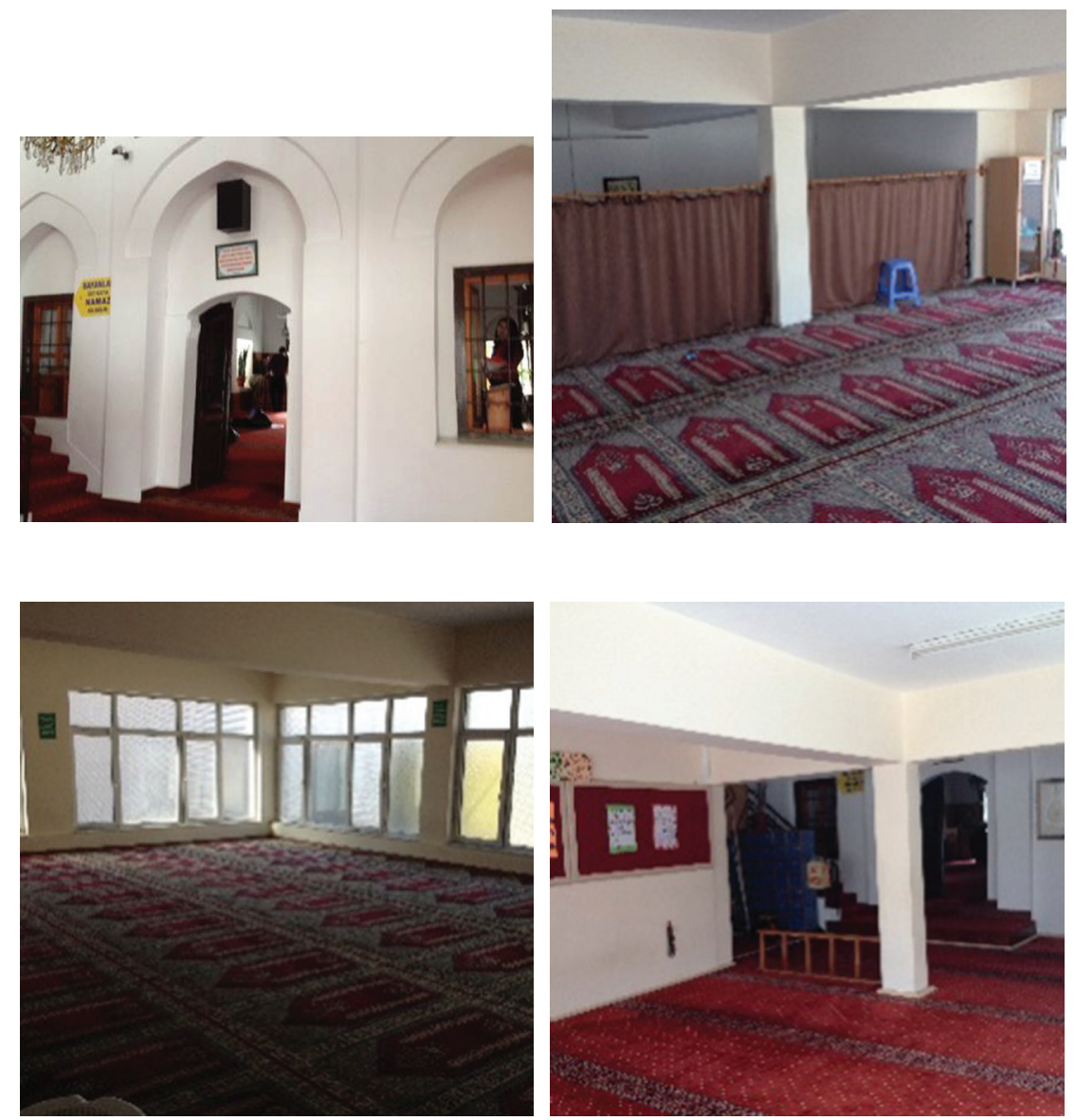

Figure 9: Interior views of the mosque and the new addition on the north side.

Source: Archives of the authors, 2016, 2018.
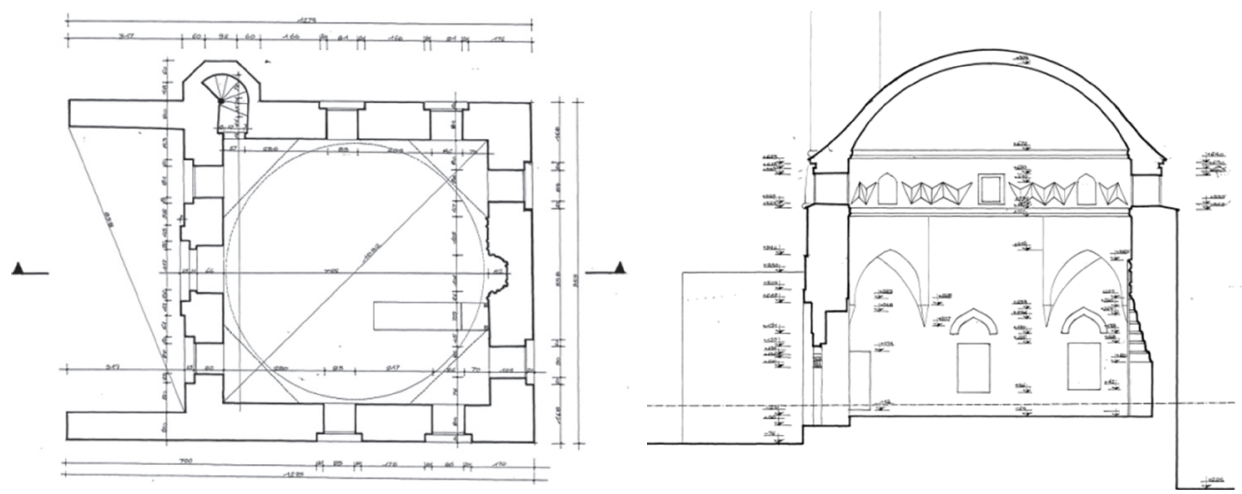

Figure 10: Plan and section drawings of Kursunlu Mosque.

Source: Archives of Directorate General of Foundations, file on Kursunlu Mosque, 1972 [22]. 


\subsection{Physical attributes and character defining elements}

The main character defining features of the mosque can be outlined as follows:

- Example of Classical Ottoman Style (central plan mosque style),

- Placed among a grouping of shops/stores that are different in scale, material, form, and type from the historic mosque,

- Dome with lead covering and brick cornices, topped with a stone finial.

- Rectangular first level windows with pointed arched toppings and pointed arched windows with brick arch surroundings at the drum of the dome.

- Two-story building sited on the corner of two streets, one is towards the Ankara Castle and the other is towards the Ulus Square,

- Rubble stone main body walls with alternating rows of bricks in between.

\subsection{Locating the mosque in the community: transport network}

Access to transit: The mosque is located at the intersection point of Anafartalar Street and Koyunpazari Street. Among them, Anafartalar Street leads to the main Ulus square, and Koyunpazarı Street connects to the historic Ankara Castle on the left. The mosque is located quite near to the bus stops, and minibus routes. There are Kursunlu and Altında Municipality public parks just on the north and south side of the mosque. Touristic Hamamonu area is also just one $\mathrm{km}$ distance to the mosque. In addition, the building is located in the combination of commercial, public, and historic buildings.

\subsection{Sustainable improvement strategies for the case study area: critical concepts}

Critical concepts for the sustainable improvement of Kursunlu Mosque and its nearby surrounding are outlined below:

- Partner with appropriate neighbourhood organizations such as Altındag Municipality for needed improvement,

- Get people involved,

- Communicate with the public, especially with the frequent users of the mosque,

- Conduct gap analysis to figure out what are the possible sustainable potentials,

- Regarding the economical side of the sustainability, make a plan for budget improvements,

- Historic preservation points; get rid of the later addition concrete building attached to the north side of the mosque, instead reconstruct the original small scale late comers' portico that once existed, and thus gain an open courtyard in front of the mosque. Restore the masonry by removing cement repointings, replacing with lime-based repointings, monitor cracks in the masonry, and replace damaged masonry as necessary, and after the restoration works, periodical maintenance of the mosque is important,

- Plant trees in suggested courtyard area that will grow to be large to treat storm water and provide shading and cooling. In addition, connect the courtyard of the mosque with the Kursunlu public park just on the north side of the building. Arrange a small area under the courtyard for ablution hall and toilets,

- Use green cleaning products and rain water collection, storm water infiltration built into infrastructure of sidewalk, provide recycling and composting, use permeable pavers, rehab water fixtures in toilets and ablution halls, use drought resistant planting in sug- 
gested courtyard area, improve indoor environmental quality by using passive heating and cooling, and natural daylighting,

- Build up the community by encouraging sympathetic new development and rehabilitation of the trade area just on the east side of the mosque with standard awnings and signboards, and give some suitable functions to some of them with the support of the Municipality, such as street café, culture house, workshops, exhibition, history and art galleries, thus provide economic gains and/or job/occupation opportunities for the neighbourhood,

- Partner with Association of Turkish Travel Agencies to reconnect the historic building to nearby historic attractions by planning an effective touristic route,

- Determine some pedestrian routes and architectural history tours in Anafartalar and Koyunpazarı neighbourhood, as well as arrange various events and children's tours, community lectures on the history of the neighbourhood and sustainability series. The route will start from the mosque continue to the citadel and end with Hac1 Bayram-1 Veli Mosque area.

- Encourage and enable linkage to Ankara Castle; develop the commercial destination at the intersection of Anafartalar Street and Koyunpazarı Street to create a strong and sustainable gateway towards the square in front of the Ankara Castle that includes needed pedestrian amenities and green path, linking Kursunlu Mosque to Ankara Castle, hence the mosque becomes a way finding element as well as the historic icon of the neighbourhood at the corner point,

- Connect and integrate the mosque with the nearby recreation opportunities such as public parks on the north and south sides, by rehabilitating those parks with suitable urban furniture and by creating children playing areas,

- All the electrical wiring and similar fixtures ruining the image of the mosque and the nearby area are to be arranged accordingly underneath the street.

- Traditional street pattern around the mosque is replaced with asphalt covering and therefore on east and north side it should be renewed with traditional stone covering,

- Parking in the area should not be allowed, instead the closed car park under the Municipality Building is to be used,

- Future plans and new programming; work with the nearby museums such as Cengel Han and Safran Han to research and support new development opportunities for the workshop organizations that might be designed in the basement of mosque courtyard.

\section{CONCLUSION}

This paper is based upon the authors' work in Ulus, Ankara. It aims to summarise the current practice of architectural conservation and adaptive resuse cases, to set up the relationship between architectural and urban conservation as well as the sustainable development of the area. In this case study area, Kursunlu Mosque and its nearby surroundings have been selected as a sub-regional case and examined in more detail in terms of its sustainable development potentials aiming to reveal the regenaration and revitalization possibilities of the existing urban core. The research results indicate that historic Ulus district still conserves its historic urban structure and architectural character to some extent. The results also show that rehabilitation and sustainable resuse cases as well as urban conservation has enhanced the tourism, economic development, and social and cultural life of the region. In addition, detailed investigation of Kursunlu Mosque case, in terms of its sustainable improvement strategies revealed that a holistic approach of architectural and urban conservation might develop the area to sustainable levels.

For future studies, it is necessary to study the environmental importance of the old city, its open spaces, gardens, infrastructure, and engaging residents in further developing the 
protection plans in cooperation with the specialized authority. It is also beneficial to encourage tourism potentials of the old city, yet without damaging its character defining feaures. Thus, it becomes possible for the residents to gain income-from the tourism potentials, and to make them feel that their traditional posessions are worth protecting.

Finally, it should be noted that, sustainable urban conservation is not a call for blind immitation of the past, but it is a call for harmonising with the old and dealing with it as a part of historic old cities. Only then it will be possible to have the ability to benefit from it in the future.

\section{REFERENCES}

[1] Rodwell, D., Sustainability and the holistic approach to the conservation of historic cities. Journal of Architectural Conservation, 9(1), pp. 58-73, 59, 2003.

[2] Basic Texts of the 1972 World Heritage Convention, 2005 Edition, Paris, France: UNESCO World Heritage Centre, p. 10. http://whc.unesco.org/uploads/activities/documents/activity-562-4.pdf

[3] Managing Cultural World Heritage; World Heritage Resource Manual, Paris, France: United Nations Educational, Scientific and Cultural Organization, pp. 12, 19, 87, 98, 2013. ISBN 978-92-3-001223-6. https://whc.unesco.org/document/125839

[4] Rodwell, D., Conservation and sustainability in Historic Cities, Blackwell Publishing: Oxford, UK, p. ix, 2007.

[5] Doak, J. \& Lynch, J., Urban Conservation Areas and Sustainable Development: Exploring the Relationship, University Of Reading Working Papers in Land Management and Development No. 10/98, November 1998.

[6] Hossam Elborombaly, Sustainable Methodology for Architecture and Urban Conservation of Heritage Areas: Theatrical and Application.

[7] Mallia, David, Sustainability and urban conservation in a small island state: the Maltese experience. Paper presented att he fifth international conference on sustainable architecture and urban development, Tripoli, Libya, 2009.

[8] Güner, B., Heritage Conservation Via Social Sustainability In Historic Urban Landscapes: Principles, Strategies And Proposals For Sakarya Quarter In Ankaral Turkey, PhD Dissertation, METU, Ankara, p. vi, 2015.

[9] Eda Ünver, Sustainability Of Cultural Heritage Management: Keklik Street And Its Surrounding Conservation And Development Project. Master's Thesis, METU, Ankara, p. iv, 2006.

[10] Konyalı, İ.H., Ankara Camileri. Ankara: VGM; 1978.

[11] Öney, G., Ankara'da Türk Devri Yapıları. Ankara: Ankara Üniversitesi Basımevi; p. 59-60, 1971.

[12] Erdoğan, A., Günel, G. \& Kılcı A., Osmanlı'da Ankara, Ankara: Ankara Büyükşehir Belediyesi, pp. 168-69, p. 320, 2007. ISBN: 9799944473065.

[13] Hmood, K.F., The Arabic Urban and Architectural Innovations, Al-Warak Publishing institution, Amman-Jordan, p. 30, pp. 63-64, 2011.

[14] Ouf, Ahmed M. Salah, Urban conservation Concepts for the New Millenium in the united Arab Emirates, Zayedcenter for heritage and history, U.A.E. heritage club, p. 34-37, 2000.

[15] Cohen, N., Urban Planning Conservation and Preservation, McGraw-Hill; New York, p. 11, pp. 13-15, p. 17, 2011.

[16] Arthur, P., Managing Tourism at World Heritage Sites, a Practical Manual for World Heritage Site Managers, UNESCO World Heritage Centre, pp. 24-94, 2002.

[17] Sousse city photos, www.google.com 
[18] Hmood, K., Aljumaily, H. \& Melnik, V., Urban, architectural heritage and sustainable tourism. WIT Transactions on Ecology and the Environment Journal, WIT press, pp. 214-227, 2018.

[19] Çelik, N., A Methodological research for the preservation of ankara citadel and citadel of urban fabric, PhD Dissertation, Mimar Sinan University of Fine Arts, Istanbul, pp. 6-11, 2000.

[20] Günel, G. \& Kılc1, A., 1924 map of Ankara City: Recognizing Ankara with an old map. Journal of Ankara Studies, 3(1), pp. 78-104, June 2015.

[21] Dişli, G., New additions to existing built heritage and their contributions to sustainable development: Cases from Ankara, Turkey. In Urban and Architectural Heritage Conservation within Sustainability, ed. Kabila Hmood, online first publication, IntechOpen, pp. 1-22, 2018. ISBN 978-953-51-7725-8. http://dx.doi.org/10.5772/intechopen. 82734

[22] Archives of Directorate General of Foundations, File on Kursunlu Mosque. 